Original Research Paper

\title{
Antifungal Activity of Jatropha Curcas Linn on Candida Albicans and Candida Tropicalis Associated with Neonatal and Infantile Infections in Yola, Nigeria
}

\author{
*James Hamuel Doughari and Martha Abraham \\ Department of Microbiology, School of Pure and Applied Sciences, \\ Modibbo Adama University of Technology, P.M.B 2076 Yola Adamawa State, Nigeria
}

\author{
Article history \\ Received: 10-12-2020 \\ Revised: 06-02-2021 \\ Accepted: 12-02-2021 \\ Corresponding Author: \\ James Hamuel Doughari \\ Department of Microbiology, \\ School of Pure and Applied \\ Sciences, Modibbo Adama \\ University of Technology, \\ P.M.B 2076 Yola Adamawa \\ State, Nigeria \\ Email: jameshamuel@yahoo.com
}

\begin{abstract}
One hundred and eighty (180) stool samples collected of neonates and infants from three selected health facilities in Yola, Adamawa State Nigeria. The samples were subjected to both microscopic, biochemical test and cultural identification. Bromocresol green agar and Germ tube test was used to identify Candida species. Culture of the stool samples on SDA yielded 32 yeast cells with Candida albicans as the predominant (90.63\%) organism isolated followed by Candida tropicalis $(9.37 \%)$. Extraction and screening for phytoconstituents of Jatropha curcas Linn parts (stem bark, leave and sap) by hot maceration using water and methanol. Showed the presence of saponins, tannins, phenols, alkanoids, steroids, flavonoids, terpenoids and glycosides. Antifungal susceptibility testing on Mueller Hinton agar, showed yeast to be susceptible to the Methanol plant extract at 400-1000 $\mu \mathrm{g} / \mathrm{mL}$ with highest diameters of zones of inhibition $(20.00 \mathrm{~mm}$ for sap, 13.00 $\mathrm{mm}$ for stem bark and $11.00 \mathrm{~mm}$ for leave) than the aqueous plant extract. All the parts of Jatropha curcas Linn showed MIC range of 400-1200 $\mu \mathrm{g} / \mathrm{mL}$ for both Candida albicans and Candida tropicalis. GC-MS study showed the presence of 11 most abundant components out of 52 compounds of the methanol leaves extract 46 compounds of methanol stem bark extracts respectively all of which demonstrated antimicrobial activity. Result also showed 12 most abundant components out of 56 compounds in sap of Jatropha curcas Linn with antimicrobial activity. Further study on the toxicity and pharmacological activity should be carried out, with a view to sourcing novel antibiotic substances for possible development of broad spectrum drugs against both bacteria and fungi.
\end{abstract}

Keywords: Antimicrobial Activity, Candida spp., Jatropha curcas, Phytochemical, Plant Extracts

\section{Introduction}

Paediatricians rendering primary health care are often faced with increase rate of fungal infection among infants and neonates. Infection due to previously uncommon hyaline and dematiaceous filamentous fungi are on increasing frequency, despite marked advances in antifungal therapy (Pappas, 2006). These opportunistic fungal infections (rare and emerging) continue to be associated with high mortality, high morbidity and poor patient outcomes in infants and neonates. There is also increased resistance to antifungal drugs commonly used for treatment of fungal infections (Romani, 2008). In addition, the rising incidences of antifungal drug resistance and the expensive nature of many antifungal drugs has resulted in many populations in the developing countries resorting to the more cheaper and readily available medicinal plants as alternatives for the treatment and control of diseases in the developing countries. Medicinal plants are the richest bio-resources of drugs for traditional medicinal systems, modern medicines, nutraceuticals, food supplements, folk medicines, pharmaceuticals and intermediate chemicals entitled for synthetic drugs, phytochemical analysis, free radical scavenging capacity and antimicrobial properties (Das et al., 2010; Anwer et al., 2013). The acceptance of traditional medicine in Nigeria as an alternative form of health care and the development of microbial resistance to available antimicrobials has led scientists to investigate the 
antimicrobial activity of medicinal plants (Rahmoun et al., 2013). In many traditions in Nigeria, different medicinal plant parts are either used singly or in combination with other parts of the same plant or of different plants in the treatment of various diseases. The treatment and control of diseases by the use of available medicinal plants will continue to play significant roles in medical health care implementation in the developing countries (Ekundayo et al., 2011).

Few studies have been reported on fungal infections of infants and neonates in this part of the world. This study will provide data on the prevalence of some pathogenic yeast in the study area, the characterization of the pathogenic yeasts isolated as well as their susceptibility profiles to commonly used synthetic antifungal agents prescribed. The traditional use of the local herb Jatropha curcas Linn for the treatment of infants and neonates against some pathogenic yeast will also be authenticated. We therefore report the antifungal activity of Jatropha curcas Linn extracts on some pathogenic yeast associated with infantile and neonate infections in Yola, Nigeria.

\section{Materials and Methods}

\section{Collection of Samples \\ Collection of Stool Samples}

The health facilities selected for this study were State Specialist Hospital, Yola, Government General Hospital, Numan and the Local Government Clinic, Sangere, Girei Local Government, all in Adamawa State Nigeria. Stool samples were collected from infants and neonates attending these three selected health facilities. Thirty (30) stool samples were collected from Local Government Clinic, Sangere, Eighty (80) from State Specialist Hospital, Yola and Seventy (70) from Government General Hospital, Numan in sterile screw-caped wide-naked specimen bottles. The bottles were properly labelled for each sample and then transported to the Microbiology Laboratory, Department of Microbiology, Modibbo Adama University of Technology, Yola within 2-3 h of collection in a cooler packed with ice blocks for processing (Bhavan et al., 2010).

\section{Collection of Plant Samples}

The plant, Jatropha curcas Linn was collected from a garden in Dakanta, Numan Local Government, Adamawa State Nigeria and identified in the Plant Science Department of Modibbo Adama University of Technology, Yola.

\section{Isolation and Identification of Yeasts}

One gramme (1 g) of stool was diluted in $9 \mathrm{~mL}$ of sterile Phosphate-Buffered Saline (PBS) and a six-fold serial dilution from $10^{-1}$ to $10^{-6}$ was prepared in PBS. Each dilution was spread in duplicate on Sabouraud Dextrose Agar (SDA) (Sigma-Aldrich, Saint-Quentin
Fallavier, France) supplemented with chloramphenicol (50 $\mu \mathrm{g} / \mathrm{mL})$. The SDA cultures were incubated aerobically at $37^{\circ} \mathrm{C}$ for $48 \mathrm{~h}$ and then examined for growth (Bhavan et al., 2010). The presumptive yeasts colonies were sub cultured on SDA slants for subsequent identification.

The yeast strains were firstly submitted to typical, micromorphological observation, culturally and biochemically. Identification of yeast cells was done the micromorphological characteristics such as cream coloured pasty colonial appearance on Sabouraud Dextrose Agar and blunt conical colonies with smooth edges and yellow to blue green colour or rough colonies, with either convex or cone shaped colonies on bromocresol green agar as presumptive for Candida species. Microscopical examination for Gram positive appearance (primary colour) after Gram staining was also used to further identify the isolates (Cheesbrough, 2005; Bhavan et al., 2010).

\section{Biochemical Identification of Yeast Cells}

Sugar fermentation tests as described by (Mpofu et al., 2008) and sugar assimilation test as described by (Tiwari et al., 2007) were used for the biochemical characterization of the presumptive yeast isolates.

For the sugar fermentation test, sugars such as raffinose, glucose, sucrose, trehalose, lactose, maltose and galactose, together with peptone from casein $1 \%$ in distilled water, distributed in separate standard assay tubes containing a Durham tube were employed as substrates in the sugar fermentation tests. A $1.5 \mathrm{~mL}$ aliquot of each sugar solution containing 6\% sugar and sterilized by filtration was placed in each tube to produce a data set from seven different carbon sources for each sample. The samples were inoculated using a $200 \mu \mathrm{L}$ aliquot in each tube, incubated at $37^{\circ} \mathrm{C}$ and readings taken after $48 \mathrm{~h}$.

For the sugar assimilation test, Yeast Carbon Base (YCB-Difco Laboratories) was used and test performed in $20 \mathrm{~mL}$ aliquots per tube as described by the manufacturer (Difco Laboratories). Each yeast sample was previously streaked on $4 \%$ Sabouraud dextrose agar to evaluate cell viability. From each sample, $1 \mathrm{~mL}$ aliquot in saline solution (equivalent to 1 McFarland standard) were dispensed into empty Petri dishes and immediately covered with liquefied YCB then cooled to $50^{\circ} \mathrm{C}$. After adding the medium, homogenizing and allowing to solidify, the carbon sources were applied at different sites on the medium and then incubated at $37^{\circ} \mathrm{C}$ for 3-7 days. Positive results for both samples were revealed by yeast growth at the sites of application.

\section{Chlamydospore Formation Test}

Identification of the yeasts was carried out morphologically using chlamydoconidia and blastoconidia formation tests as described by (Jha et al., 2006; Bhavan et al., 2010). Briefly, one loopful of fungi was mixed with a $0.2 \mathrm{~mL}$ phosphate buffered solution to 
create a dense fungal solution equivalent to approximately $10^{6}$ cells $/ \mathrm{mL}$. Then, this was mixed with $1 \mathrm{~mL}$ broth to create a fungal suspension for incubation. Fifty microliter $(50 \mu \mathrm{L})$ of the fungal solution was placed on a sterile glass slide and the glass slide placed in a wet Petri dish without a cover glass. The Petri dish was further sealed with a vinyl bag and the fungi were incubated at $37^{\circ} \mathrm{C}$. After incubation, cultured specimens were collected and fungal morphology observed in an optical microscope for chlamydoconidia and blastoconidia formation.

\section{Germ Tube Test}

The germ tube test as described by (Matare et al., 2017) was used to further confirm the identity of yeasts in the samples. Briefly, to triplicate sets of test tubes containing $0.5-1.0 \mathrm{~mL}$ of pooled human serum were inoculated 2-3 colonies of each isolate and the tubes inoculated at $37^{\circ} \mathrm{C}$ for $3 \mathrm{~h}$. After incubation, a drop of each suspension was placed on labeled microscope slides for examination of germ tubes. Confirmed yeast cells were subcultured onto plates of Sabouraud's Dextrose Agar and then preserved in a refrigerator at $4^{\circ} \mathrm{C}$ until use.

\section{Plant Sample Preparation and Extraction of Active Phytoconstituents}

Plant sample collected was washed thoroughly with tap water and then twice with distilled water, separated manually (the leaves and the stem bark), then allowed to dry for 5 days to constant weight at ambient temperature. The dried plant materials (leaf and stem bark) were crushed separately to powder with pestle and mortar. Twenty grammes $(20 \mathrm{~g})$ each of the stem bark powder and leaf was macerated in $250 \mathrm{~mL}$ of solvent (90\% Methanol) and $250 \mathrm{~mL}$ of distilled water, placed in a conical flask and refluxed at $45^{\circ} \mathrm{C}$ for 60 min separately (Chen et al., 2007) and filtered using Whitman's filter paper (pore size $11 \mu \mathrm{m})$. The filtrate obtained was concentrated to dryness in water bath at $40^{\circ} \mathrm{C}$ and the crude extract was weighted and kept dry in desiccators.

\section{Phytochemical Screening of the Aqueous Extracts of Jatropha curcas Linn}

Qualitative and quantitative phytochemical screening of the aqueous extracts of Jatropha curcas Linn for the presence of secondary metabolites (tannins, saponins, flavonoids, terpenoids, steroids, phenols, alkaloids and glycosides) was carried out (Sofowora, 1996).

\section{Antifungal Susceptibility Assay of Plant Extracts}

\section{Preparation of the Inoculum and Performance of Test}

Sabouraud's Dextrose Agar was used to grow the yeast isolates and subcultured twice to ensure purity and viability. The yeast isolate was then suspended in $5 \mathrm{~mL}$ of sterile $0.85 \mathrm{NaCl}$. The turbidity of the suspension was measured spectrophotometrically at $530 \mathrm{~nm}$ and adjusted with sterile saline to 0.5 McFarland Standard (equivalent to $10^{6}$ cells $/ \mathrm{mL}$ ).

\section{Antifungal Susceptibility Test}

Mueller Hinton agar was prepared according to Manufacturer's specification. The prepared medium was sterilized at $14^{\circ} \mathrm{C}$ for $15 \mathrm{~min}$, dispensed in Petri dishes and allowed to solidity. Wells were then bored onto the solidified Mueller Hinton agar media using a sterile $6 \mathrm{~mm}$ depth cork borer (Obidi et al., 2013). Using sterile pipette, $0.1 \mathrm{~mL}$ of the culture suspension was inoculated on into the wells on the Mueller Hinton agar plates and a bent glass rod used to spread the yeast inoculums evenly on the surface of the media and the plate then allowed to dry. The wells were filled with the solution of the extract of approximately $100 \mu \mathrm{g} / \mathrm{mL}$ of various concentrations $(200,400,600,800$ and 1000 $\mu \mathrm{g} / \mathrm{mL}$ ), taking care not to allow spillage of the solution to the surface of the agar medium. The plates were allowed to stand on the laboratory bench for $1 \mathrm{~h}$ to allow proper diffusion of the extract into the media. The culture plates were incubated at $37^{\circ} \mathrm{C}$ for $24 \mathrm{~h}$ and later observed for diameters of zones of inhibition. Nystatin suspension was used as a positive control (Esimone et al., 1998).

\section{Determination of Minimum Inhibitory Concentration (MIC) and Minimum Fungicidal Concentration (MFC)}

The MICs were determined according to the method of (Borman et al., 2017). To a series of broth cultures of Candida isolates (0.5 McFarland Standard) prepared in six different test tubes each containing $10 \mathrm{~mL}$ of Potato Dextrose Broth, $1.0 \mathrm{~mL}$ of various plant extract concentrations (200, 400, 600, 800, 1000 and 1200 $\mu \mathrm{g} / \mathrm{mL}$ ) was added respectively. A set of test tubes one containing broth Candida and broth alone (negative control) and the other containing culture broth and 30 $\mu \mathrm{g} / \mathrm{mL}$ (positive control) were used as controls. All the broth cultures were incubated for $37^{\circ} \mathrm{C}$ for $24 \mathrm{~h}$ and then examined for growth. The lowest concentration without visible growth was taken as the MICs for the isolates. The lowest concentration without visible growth for the isolates from MIC above was sub-cultured on fresh plates of Sabouraud Dextrose Agar plates and incubated $37^{\circ} \mathrm{C}$ for $24 \mathrm{~h}$. After incubation, the plates were examined visually for colonies and the plates with plant extract concentration that showed no visible growth were regarded as MFC of the isolates (Borman et al., 2017).

Gas Chromatography-Mass Spectrophotometry (GC-MS) Analysis of Jatropha curcas Linn Extracts

The chromatographic procedure was carried out using a 7890A GC system (Agilent Technologies), equipped with a Mass Selective injector (MSD) 5975 (Agilent Technologies), injector series model 7683B and HP-5MS capillary column 
( $30 \mathrm{~m} \times 0.320 \mathrm{~mm}, 0.25 \mu \mathrm{m}$ film thickness). The temperature of the column was maintained at $350^{\circ} \mathrm{C}$ for $1 \mathrm{~min}$. It was then raised at the rate of $100^{\circ} \mathrm{C}$ per min for a hold time of $3 \mathrm{~min}$. Finally, the temperature of the injection port was maintained at $2200^{\circ} \mathrm{C}$ and that of the detector at $2500^{\circ} \mathrm{C}$ for $3 \mathrm{~min}$ hold time. This was adapted in order to prevent excess long chain fatty acids from accumulating on the GC column. Helium was the carrier gas. The following parameters were maintained: Pressure $=112.0 \mathrm{kPa}$, Total flow $=32.7 \mathrm{ml} / \mathrm{min}$, Column flow $=1.90 \mathrm{~mL} / \mathrm{min}$, Linear velocity $=50 \mathrm{~cm} / \mathrm{sec}$. The chromatographic effluent was then analyzed by the MSD (Obidi et al., 2013).

\section{Data Analysis}

Data was analyzed using percentage and ChiSquared $\operatorname{Test}\left(\mathrm{X}^{2}\right)$ at $\mathrm{P}=0.5$ to compare the antifungal effect of standard antifungal drugs and extracts from Jatropha curcas Linn against yeast isolated from neonates and infants.

\section{Results}

Of the 80 (out of the total of 180 samples collected) stool samples from State Specialist Hospital Yola, 14 (17.8\%) were positive for Candida species, for the 70 samples from Government General Hospital. Numan, 10 (14.29\%) were positive for Candida species and of the 30 collected from Local Government Clinic, Sangere 8 (26.7\%) were positive for Candida species (Table 1). The statistical analysis showed that there is no significant difference in the level of Candida species occurrence in the different sample sites at $5 \%$ level of significance.

The phytochemical analysis of plant extracts in this study revealed the presence of phenol, tannins, alkaloids, glycosides, steroids, flavonoids, terpenoids and saponins compounds with phenolic compounds having the highest concentration in the leave, stem bark and sap extracts of Jatropha curcas Linn (Tables 2 and 3). This agree with earlier works of (Akinpelu et al., 2009; Igbinosa et al., 2009; Nwala et al., 2013) who reported the presence of saponins, tannins, flavonoids, alkaloids and glycosides in the methanol leaf extracts of Jatropha curcas Linn.

Result of antifungal susceptibility testing of the partially purified methanol fraction of aqueous leave and stem bark extracts showed that Candida albicans exhibited resistance against the extracts at 200-1000 $\mu \mathrm{g} / \mathrm{mL}$ (Table $4 \mathrm{a}$ and $4 \mathrm{~b}$ ). The methanol fraction of aqueous leaves and stem bark aqueous extract of Jatropha curcas Linn, showed very low diameter of zone of inhibition $(5.00 \mathrm{~mm})$ at high 600,800 $\mu \mathrm{g} / \mathrm{mL}(7.00 \mathrm{~mm})$ and $1000 \mu \mathrm{g} / \mathrm{mL}(10.00 \mathrm{~mm})$. This is in agreement with the study of (Ishak et al., 2011) who reported that the methanol leaves and pericarp extracts possessed significant activities against some pathogenic fungi at high concentration than aqueous extracts. Result also showed that the sap extract of Jatropha curcas Linn, showed the highest antimicrobial activity than both Methanol and aqueous extracts of leave and stem bark with the highest diameter of zone of inhibition $(21.00 \mathrm{~mm}$ ) at $1000 \mu \mathrm{g} / \mathrm{mL}$ (Table $4 \mathrm{~b}$ ). This correlates with the observation previously reported by (Aransiola et al., 2014; Abubakar et al., 2016).

The result obtained for Minimum Inhibitory Concentration (MIC) and Minimum Fungicidal Concentration (MFC) (Table 5) showed that the MIC values of the sap extract, methanol stem bark extract, methanol leave extract, aqueous leave extract and aqueous stem bark extract was lower (400-1200 $\mu \mathrm{g} / \mathrm{mL})$ than those of MFC (800-1800 $\mu \mathrm{g} / \mathrm{mL})$. These findings correlate with the reports by (Joanne et al., 2008; Arekemase et al., 2011; Sundari and Selvaraj, 2011) that organisms varied widely in the degree of their susceptibility.

The Gas Chromatography Mass Spectroscopy (GC-MS) result obtained from methanol fraction of sap extract indicated the presence of 56 compounds (Table 6a) and the chromatogram (Fig. 1). The most abundant of these compounds included 1, 2-Benzenedicarboxylic acid, butyl 2ethylhexyl ester $(29.16 \%$ area percentage $)$ and Quinolin-5(6H)-one, 7, 8-dihydro-2-hydroxy-4, 7, 7trimethyl (4.08\%) area percentage. The Gas Chromatography Mass Spectroscopy (GC-MS) result obtained from methanol fraction of methanol stem bark extract and the methanol fraction of methanol leave extract indicated the presence of 46 and 52 compounds respectively (Tables 6 a to $6 \mathrm{c}$ ) and the chromatogram (Figs. 2 and 3). The compounds that occurred in abundance were 2(Octyloxycarbonyl) benzoic acid (13.32\% area percentage), dichloroaceticacid, 2-pentadecyl ester $(11.68 \%$ area percentage), 3-Chlorophenyl carbamic acid, 5,6,7,8tetrahydronaphthalen-2-yl ester $(9.78 \%$ area percentage $)$ and 7, Oabicyclo[4.1.0]heptanes, 1,5-dimethyl (7.70\% area percentage), which was also reported by (Ujjwal et al., 2008; El-Baz et al., 2015). The GC-MS result obtained from methanol fraction of methanol leaf extract are Ricinoleic acid (8.36\% area percentage). Ujjwal et al. (2008) had earlier reported antifungal activity of these fatty acids detected in seeds of Jatropha curcas Linn (a hydroxyl group compound). Result also showed the presence of Pyrroledrelethyl-3,2' spiro-benzo-1-3 dioxalane $(7.05 \%$ area percentage), Adipic acid, 2-ethylhexyl isobutyl ester $(6.50 \%$ area percentage) and 2-Cyano-2-(3,4-dichloro-5(2H)-oxo-2furyl) acetamine $(5.10 \%$ area percentage). In accordance with the present work, (El-Baz et al., 2015; Kala et al., 2011) as well as (Youssef and Amin, 2010) reported the presence of these compounds in methanol, ethanol and aqueous leave and stembark extracts of Jatropha curcas Linn in their the GC-MS analysis. Many spiro compounds were also detected in sap, leaves and stem bark extracts of Jatropha curcas Linn in this study. Furthermore, result showed that the GC-MS of methanol fraction methanol stem bark, sap and leave extract showed the presence of Hexadecenoic acid, Z-11. 
James Hamuel Doughari and Martha Abraham / American Journal of Agricultural and Biological Sciences 2021, Volume 16: 19.32 DOI: 10.3844/ajabssp.2021.19.32

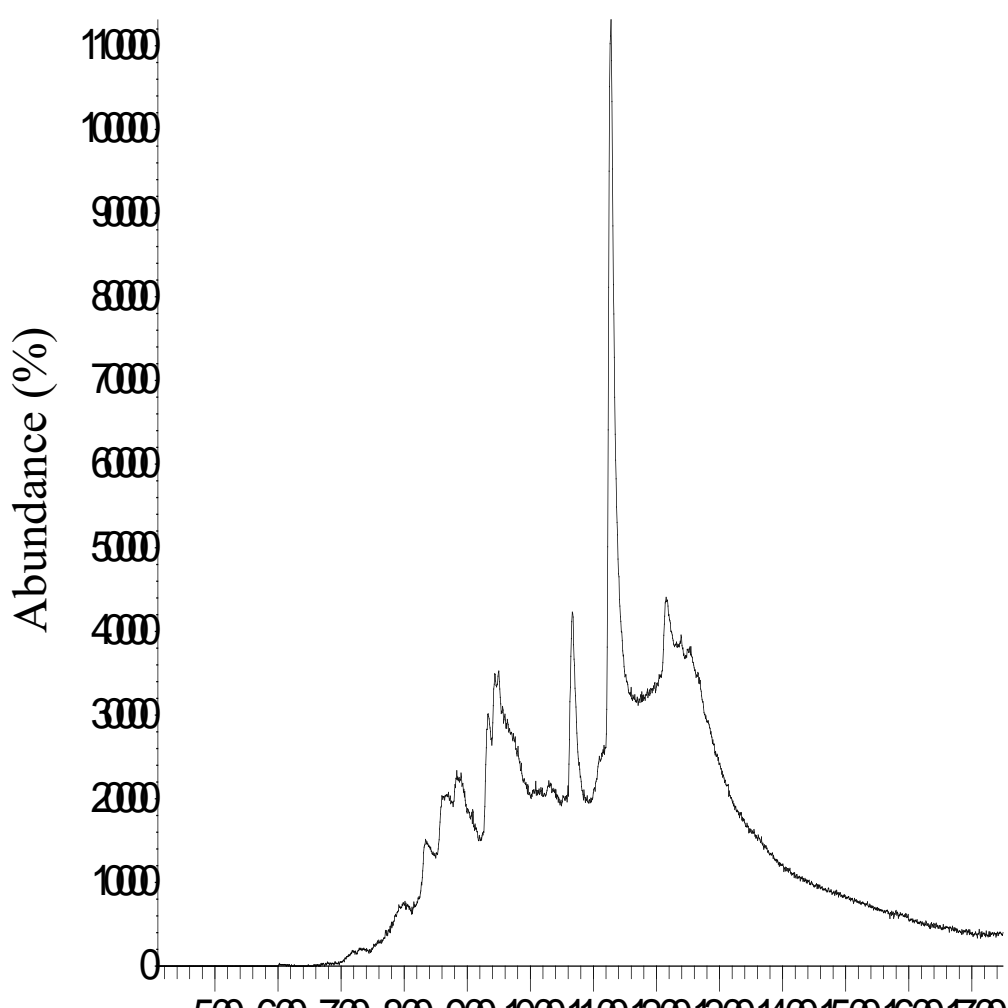

506007.00800900100011 .0120013001401500160017 .00

Fig. 1: Gas chromatogram of Jatropha curcas Linn sap

Abundance

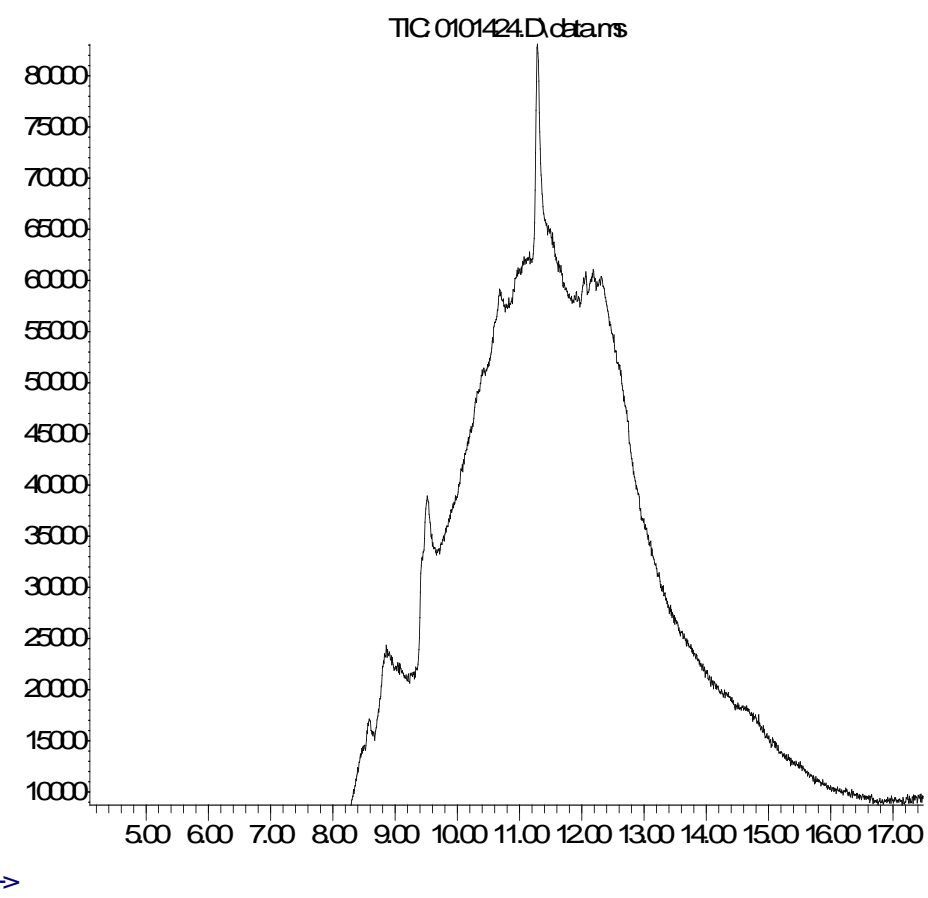

Fig. 2: Gas chromatogram of methanolic stem bark extract of Jatropha curcas Linn 


\section{Abundance}

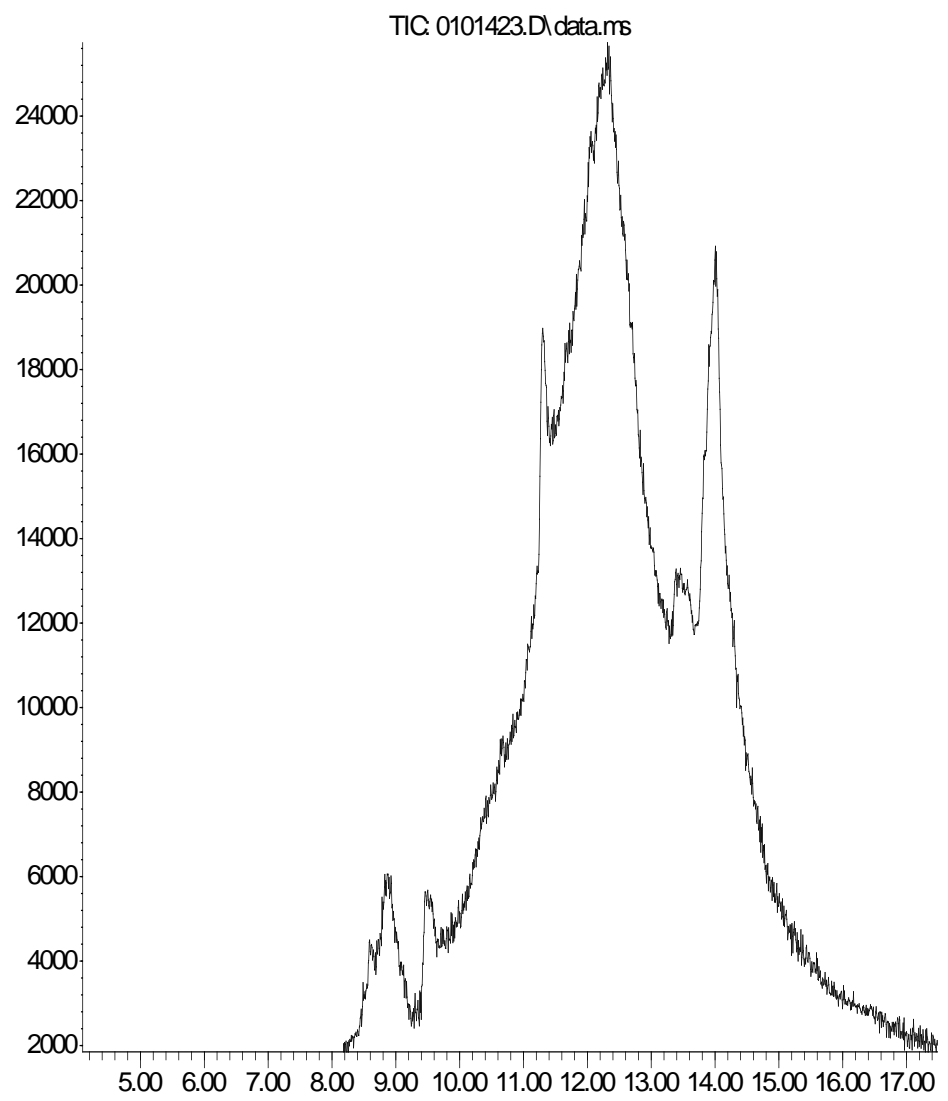

Time $\rightarrow$

Fig. 3: Gas chromatogram of methanolic leaves extract of Jatropha curcas Linn

Table 1: Distribution of stool samples collected and occurrence of Candida spp from study area

\begin{tabular}{llll}
\hline Sample site & No. of samples collected & No. + ve for Candida & Percentage $X^{2}$ \\
\hline Specialist Hospital Yola & 80 & $14(17.5)$ & $X^{2}$ Cal $<X^{2}$ tab \\
& & & $X^{2} \mathrm{Cal}=2.21$ \\
General Hospital Numan & 70 & $10(14.29)$ & $X^{2} \mathrm{Tab}=5.99$ \\
Sangere Clinic & 30 & $8(26.67)$ & \\
Total & 180 & 32 & \\
\hline
\end{tabular}

Key: + ve = positive

Table 2: Qualitative phytochemical composition of Jatropha curcas Linn extracts

\section{Solvent extracts}

\begin{tabular}{lllll} 
Phytochemicals & ML & Sap & MS & AL \\
\hline Saponins & + & + & + & + \\
Flavonoids & + & + & + & + \\
Terpenoids & + & + & + & + \\
Alkaloids & + & + & + & + \\
Steroids & + & + & + & + \\
Tannins & + & + & + & + \\
Phenols & + & + & + & + \\
Glycosides & + & + & +
\end{tabular}

MS = Methanolic Stem bark extract, ML = Methanolic Leaves extract, AS = Aqueous Stem bark extract, AL = Aqueous Leaves extract Sap = Sap of Jatropha curcas Linn, - = Negative, $+=$ Positive 
Table 3: Quantitative phytochemical composition of Jatropha curcas Linn extracts

Composition (\%) of components in extracts

\begin{tabular}{|c|c|c|c|c|c|}
\hline Phytochemicals & ML & Sap & MS & $\mathrm{AL}$ & AS \\
\hline Saponins & 0.48 & 0.26 & 1.24 & 0.20 & 0.12 \\
\hline Flavonoids & 1.63 & 3.14 & 0.82 & 0.52 & 1.00 \\
\hline Terpenoids & 0.15 & 2.04 & 0.12 & - & - \\
\hline Alkaloids & 3.13 & 4.11 & 4.53 & 1.34 & 1.53 \\
\hline Steroids & 1.85 & 3.76 & 2.95 & 0.78 & 1.34 \\
\hline Tannins & 4.07 & 6.78 & 2.80 & 1.43 & 1.98 \\
\hline Phenols & 14.12 & 15.42 & 14.56 & 7.65 & 8.02 \\
\hline Glycosides & 2.01 & 4.21 & 1.74 & - & - \\
\hline
\end{tabular}

MS = Methanolic Stem bark extract, ML = Methanolic Leaves extract, AS = Aqueous Stem bark extract, AL = Aqueous Leaves extract Sap = Sap of Jatropha curcas Linn, - = Negative, $+=$ Positive

Table 4a: Mean values of antimicrobial activity of methanol fractions of different parts of Jatropha curcas Linn on yeast isolates after purification

\begin{tabular}{|c|c|c|c|c|c|c|c|c|c|c|c|c|}
\hline \multirow[b]{3}{*}{ Sample } & \multicolumn{12}{|c|}{ Mean diameters of zones of inhibition $(\mathrm{mm})$ for the various extracts $(\mu \mathrm{g})$} \\
\hline & \multicolumn{2}{|l|}{ MFMS } & \multicolumn{2}{|l|}{ MFML } & \multicolumn{2}{|l|}{ MFAL } & \multicolumn{2}{|l|}{ MFAS } & \multicolumn{2}{|l|}{ MFS } & \multicolumn{2}{|l|}{$\mathrm{N}$} \\
\hline & $200 \mu \mathrm{g}$ & $400 \mu \mathrm{g}$ & $200 \mu \mathrm{g}$ & $400 \mu \mathrm{g}$ & $200 \mu \mathrm{g}$ & $400 \mu \mathrm{g}$ & $200 \mu \mathrm{g}$ & $400 \mu \mathrm{g}$ & $200 \mu \mathrm{g}$ & $400 \mu \mathrm{g}$ & $200 \mu \mathrm{g}$ & $400 \mu \mathrm{g}$ \\
\hline 1. & 2.00 & 3.00 & 0.60 & 0.92 & 0.00 & 0.00 & 0.00 & 0.09 & 7.00 & 8.00 & 8.00 & 6.00 \\
\hline 2. & 4.00 & 4.00 & 2.66 & 3.16 & 0.00 & 0.10 & 1.02 & 1.22 & 9.33 & 9.63 & 9.66 & 8.66 \\
\hline 3. & 2.00 & 3.10 & 2.33 & 2.33 & 0.00 & 0.00 & 2.00 & 2.00 & 7.00 & 5.60 & 6.66 & 6.33 \\
\hline 4. & 2.00 & 2.20 & 1.60 & 2.60 & 0.00 & 0.30 & 1.33 & 1.84 & 8.33 & 8.03 & 8.00 & 8.33 \\
\hline 5. & 2.60 & 3.20 & 3.33 & 4.01 & 0.00 & 0.00 & 1.66 & 1.68 & 9.00 & 9.50 & 9.66 & 7.13 \\
\hline 6. & 1.66 & 3.66 & 0.00 & 0.00 & 0.00 & 0.00 & 0.06 & 0.96 & 8.66 & 8.96 & 10.00 & 6.33 \\
\hline 7. & 0.00 & 1.56 & 0.00 & 0.91 & 0.00 & 1.00 & 0.00 & 0.60 & 2.00 & 3.90 & 0.00 & 4.00 \\
\hline 8. & 3.66 & 4.76 & 3.00 & 3.99 & 0.00 & 0.00 & 2.00 & 2.10 & 9.00 & 9.50 & 10.33 & 11.00 \\
\hline 9. & 4.00 & 4.90 & 3.66 & 4.54 & 0.00 & 0.50 & 3.00 & 3.09 & 8.20 & 9.20 & 10.33 & 7.33 \\
\hline 10. & 1.66 & 1.96 & 0.00 & 0.72 & 0.00 & 0.00 & 0.10 & 0.10 & 4.90 & 3.90 & 4.66 & 4.00 \\
\hline 11. & 4.00 & 4.60 & 0.00 & 2.12 & 0.00 & 0.40 & 0.33 & 2.03 & 5.66 & 5.66 & 4.33 & 7.66 \\
\hline 12. & 3.60 & 2.60 & 2.33 & 2.99 & 0.00 & 0.00 & 0.01 & 1.11 & 6.33 & 6.33 & 6.00 & 6.66 \\
\hline 13. & 3.26 & 4.06 & 3.32 & 4.01 & 0.00 & 0.00 & 1.00 & 1.90 & 8.00 & 9.00 & 9.33 & 8.33 \\
\hline 14. & 3.00 & 3.80 & 0.00 & 0.33 & 0.00 & 2.00 & 1.33 & 1.93 & 6.33 & 6.53 & 6.66 & 7.00 \\
\hline 15. & 3.53 & 3.90 & 1.66 & 2.16 & 0.00 & 0.00 & 1.00 & 1.80 & 9.01 & 10.01 & 10.33 & 12.00 \\
\hline 16. & 4.60 & 5.01 & 3.33 & 3.54 & 0.00 & 0.00 & 2.00 & 2.09 & 10.33 & 9.33 & 8.23 & 9.66 \\
\hline 17. & 4.30 & 4.39 & 4.00 & 4.63 & 0.00 & 0.00 & 1.66 & 1.68 & 10.93 & 12.43 & 11.00 & 13.00 \\
\hline 18. & 3.10 & 3.91 & 0.00 & 1.00 & 0.00 & 0.00 & 2.66 & 3.00 & 9.00 & 9.00 & 8.33 & 11.66 \\
\hline 19. & 2.66 & 3.66 & 0.00 & 0.94 & 0.00 & 1.01 & 1.33 & 3.33 & 9.00 & 9.20 & 9.33 & 8.00 \\
\hline 20. & 2.66 & 3.66 & 1.33 & 1.84 & 0.00 & 0.00 & 0.00 & 3.00 & 8.00 & 8.50 & 9.00 & 9.00 \\
\hline 21. & 4.00 & 4.70 & 2.00 & 2.74 & 0.00 & 0.01 & 0.66 & 2.66 & 8.66 & 8.06 & 8.00 & 9.33 \\
\hline 22. & 3.00 & 3.92 & 0.00 & 1.01 & 0.00 & 0.00 & 0.06 & 1.06 & 9.00 & 11.90 & 9.00 & 10.33 \\
\hline 23. & 3.06 & 4.16 & 0.00 & 2.00 & 0.00 & 0.20 & 0.00 & 1.90 & 8.66 & 6.06 & 9.33 & 5.66 \\
\hline 24. & 5.76 & 6.01 & 3.00 & 3.30 & 0.00 & 0.00 & 1.03 & 1.83 & 8.99 & 9.09 & 8.33 & 9.66 \\
\hline 25. & 4.26 & 4.71 & 2.00 & 2.12 & 0.00 & 0.00 & 0.10 & 2.00 & 8.00 & 7.50 & 8.00 & 8.00 \\
\hline 26. & 3.33 & 4.91 & 2.00 & 2.91 & 0.00 & 1.00 & 0.20 & 0.20 & 5.66 & 5.06 & 5.33 & 7.00 \\
\hline 27. & 3.13 & 5.13 & 4.00 & 4.67 & 0.00 & 0.00 & 1.00 & 1.67 & 6.00 & 6.50 & 6.33 & 7.00 \\
\hline 28. & 3.00 & 3.20 & 2.00 & 3.10 & 0.00 & 0.00 & 0.00 & 0.99 & 8.66 & 8.99 & 9.00 & 9.20 \\
\hline 29. & 4.00 & 5.01 & 1.33 & 2.43 & 0.00 & 0.10 & 0.06 & 0.09 & 7.50 & 7.59 & 8.00 & 8.00 \\
\hline 30. & 4.01 & 5.00 & 3.00 & 3.56 & 0.00 & 0.00 & 1.06 & 2.16 & 9.33 & 9.00 & 8.00 & 8.66 \\
\hline 31. & 3.56 & 3.76 & 0.00 & 0.92 & 0.00 & 0.01 & 1.00 & 1.90 & 9.33 & 9.45 & 9.00 & 9.66 \\
\hline 32. & 3.43 & 5.00 & 0.00 & 1.40 & 0.00 & 0.00 & 0.00 & 2.00 & 6.33 & 6.33 & 7.60 & 8.33 \\
\hline
\end{tabular}

MFMS = Methanol Fraction Methanolic Stem bark extract, MFML = Methanol Fraction Methanolic Leaves extract, MFAS = Methanol Fraction Aqueous Stem bark extract, MFAL = Methanol Fraction Aqueous Leaves extract, MFS $=$ Methanol Fraction Sap, N = Nystatin suspension 
James Hamuel Doughari and Martha Abraham / American Journal of Agricultural and Biological Sciences 2021, Volume 16: 19.32 DOI: 10.3844/ajabssp.2021.19.32

Table 4b: Mean values of antimicrobial activity of methanol fractions of different parts of Jatropha curcas Linn on yeast isolates after purification

\begin{tabular}{|c|c|c|c|c|c|c|c|c|c|c|c|c|}
\hline \multirow[b]{3}{*}{ Sample } & \multicolumn{12}{|c|}{ Mean diameters of zones of inhibition $(\mathrm{mm})$ for the various extracts $(\mu \mathrm{g})$} \\
\hline & \multicolumn{2}{|l|}{ MFMS } & \multicolumn{2}{|l|}{ MFML } & \multicolumn{2}{|l|}{ MFAL } & \multicolumn{2}{|l|}{ MFAS } & \multicolumn{2}{|l|}{ MFS } & \multicolumn{2}{|l|}{$\mathrm{N}$} \\
\hline & $400 \mu \mathrm{g}$ & $800 \mu \mathrm{g}$ & $400 \mu \mathrm{g}$ & $800 \mu \mathrm{g}$ & $400 \mu \mathrm{g}$ & $800 \mu \mathrm{g}$ & $400 \mu \mathrm{g}$ & $800 \mu \mathrm{g}$ & $400 \mu \mathrm{g}$ & $800 \mu \mathrm{g}$ & $400 \mu \mathrm{g}$ & $800 \mu \mathrm{g}$ \\
\hline 1. & 7.30 & 9.33 & 8.00 & 10.20 & 3.000 & 5.00 & 4.00 & 7. 00 & 10.00 & 12.50 & 11.00 & 13.00 \\
\hline 2. & 6.00 & 11.40 & 6.30 & 8.30 & 2.100 & 4.90 & 4.00 & 4.50 & 13.00 & 14.30 & 11.00 & 15.33 \\
\hline 3. & 6.30 & 7.60 & 7.00 & 6.00 & 3.000 & 3.30 & 5.60 & 5.60 & 18.30 & 19.30 & 14.00 & 10.66 \\
\hline 4. & 8.10 & 10.00 & 6.60 & 9.20 & 2.200 & 6.00 & 4.00 & 6.30 & 17.00 & 18.30 & 15.00 & 15.00 \\
\hline 5. & 11.10 & 11.00 & 9.30 & 10.00 & 1.000 & 5.20 & 3.00 & 5.00 & 15.00 & 13.20 & 17.00 & 15.00 \\
\hline 6. & 6.00 & 5.66 & 6.60 & 5.00 & 3.000 & 1.20 & 4.00 & 4.00 & 10.00 & 11.00 & 11.00 & 10.50 \\
\hline 7. & 6.50 & 7.90 & 6.00 & 7.10 & 2.300 & 3.30 & 5.00 & 6.60 & 10.00 & 10.00 & 12.00 & 12.00 \\
\hline 8. & 7.00 & 10.10 & 7.60 & 8.00 & 2.300 & 5.00 & 3.40 & 8.00 & 12.00 & 13.00 & 11.60 & 13.30 \\
\hline 9. & 9.10 & 5.90 & 6.00 & 5.00 & 1.990 & 3.43 & 2.60 & 5.50 & 10.30 & 11.00 & 11.60 & 12.00 \\
\hline 10. & 6.30 & 5.90 & 7.00 & 5.30 & 2.230 & 2.10 & 5.70 & 6.00 & 10.00 & 11.60 & 12.00 & 11.00 \\
\hline 12. & 7.20 & 8.99 & 6.00 & 7.30 & 0.300 & 2.00 & 4.10 & 6.00 & 10.60 & 10.00 & 9.30 & 9.00 \\
\hline 13. & 7.40 & 10.00 & 6.00 & 8.00 & 1.660 & 3.70 & 2.33 & 4.00 & 15.33 & 17.00 & 17.66 & 20.00 \\
\hline 14. & 8.33 & 9.10 & 8.00 & 8.00 & 3.100 & 5.60 & 3.66 & 7.00 & 11.33 & 13.00 & 12.00 & 13.00 \\
\hline 15. & 7.66 & 10.10 & 5.00 & 9.20 & 2.100 & 5.11 & 5.33 & 2.50 & 11.00 & 14.00 & 12.00 & 13.00 \\
\hline 16. & 8.93 & 7.00 & 8.00 & 6.20 & 0.600 & 4.30 & 6.60 & 5.00 & 12.30 & 12.00 & 14.00 & 15.00 \\
\hline 17. & 9.00 & 9.73 & 8.33 & 9.30 & 1.000 & 4.50 & 4.99 & 6.00 & 12.00 & 11.00 & 13.33 & 13.00 \\
\hline 18. & 11.50 & 10.20 & 9.00 & 10.60 & 2.530 & 5.00 & 3.00 & 6.00 & 14.30 & 15.00 & 16.66 & 17.00 \\
\hline 19. & 9.76 & 11.00 & 7.00 & 10.00 & 2.600 & 4.30 & 5.50 & 5.00 & 18.66 & 19.00 & 17.00 & 20.00 \\
\hline 20. & 8.66 & 8.90 & 7.00 & 10.00 & 0.500 & 2.90 & 3.03 & 1.00 & 12.33 & 14.00 & 15.60 & 16.00 \\
\hline 21. & 9.70 & 9.70 & 8.00 & 10.00 & 3.000 & 5.00 & 4.43 & 6.00 & 14.33 & 15.00 & 17.00 & 17.00 \\
\hline 22. & 9.20 & 9.00 & 7.33 & 9.00 & 5.400 & 5.30 & 3.99 & 6.00 & 14.00 & 13.00 & 14.00 & 15.00 \\
\hline 23. & 10.03 & 8.97 & 6.00 & 9.00 & 4.100 & 3.00 & 4.66 & 4.60 & 11.00 & 11.00 & 12.00 & 12.00 \\
\hline 24. & 8.06 & 11.10 & 7.66 & 10.00 & 3.500 & 5.00 & 5.00 & 5.00 & 10.33 & 19.30 & 13.33 & 20.00 \\
\hline 26. & 9.00 & 9.30 & 6.33 & 9.00 & 1.100 & 5.00 & 4.00 & 4.00 & 11.33 & 12.00 & 12.60 & 11.00 \\
\hline 27. & 7.21 & 8.20 & 6.00 & 8.00 & 2.100 & 6.00 & 3.60 & 5.00 & 11.30 & 12.00 & 13.00 & 14.00 \\
\hline 28. & 8.99 & 10.00 & 7.00 & 9.00 & 0.300 & 3.40 & 3.00 & 3.00 & 13.00 & 12.00 & 12.00 & 13.00 \\
\hline 29. & 8.00 & 10.30 & 6.00 & 10.00 & 4.200 & 4.00 & 5.00 & 3.50 & 12.30 & 13.00 & 14.00 & 14.00 \\
\hline 30. & 9.00 & 10.60 & 7.00 & 10.00 & 3.700 & 6.00 & 6.00 & 7.00 & 15.00 & 15.00 & 13.60 & 14.00 \\
\hline 31. & 6.49 & 10.00 & 5.33 & 9.00 & 3.030 & 6.10 & 7.00 & 5.00 & 13.00 & 13.00 & 12.00 & 14.00 \\
\hline 32. & 8.45 & 6.00 & 5.60 & 6.00 & 4.000 & 4.00 & 3.00 & 5.00 & 12.33 & 10.00 & 7.00 & 8.00 \\
\hline
\end{tabular}

MFMS = Methanol Fraction Methanolic stem bark extract, MFML = Methanol Fraction Methanolic leaves extract, MFAS= Methanol Fraction Aqueous stem bark extract, MFAL = Methanol Fraction Aqueous leaves extract, MFS = Methanol Fraction Sap, N = Nystatin suspension

Table 5: Determination of Minimum Inhibitory Concentration (MIC) and Minimum Fungicidal Concentration (MFC) of Crude Extract of Different Part of Jatropha curcas Linn

\begin{tabular}{llrr}
\hline Yeast isolates & Jatropha curcas Linn extract & MIC value $(\mu \mathrm{g} / \mathrm{ml})$ & MFC value $(\mu \mathrm{g} / \mathrm{ml})$ \\
\hline Candida albicans & MS & 500 & 1000 \\
& ML & 800 & 1200 \\
& AS & 1000 & 1400 \\
& AL & 1200 & 1600 \\
Candida tropicalis & S & 400 & 800 \\
& MS & 600 & 1000 \\
& ML & 800 & 1200 \\
& AS & 1000 & 1400 \\
& AL & 1400 & 1800 \\
\end{tabular}

MS = Methanolic Stem exract, ML = Methanolic Leaves extract, AS = Aqueous Stem extract, AL = Aqueous Leaves extract, $\mathrm{S}=\mathrm{Sap}$ extract 
James Hamuel Doughari and Martha Abraham / American Journal of Agricultural and Biological Sciences 2021, Volume 16: 19.32 DOI: 10.3844/ajabssp.2021.19.32

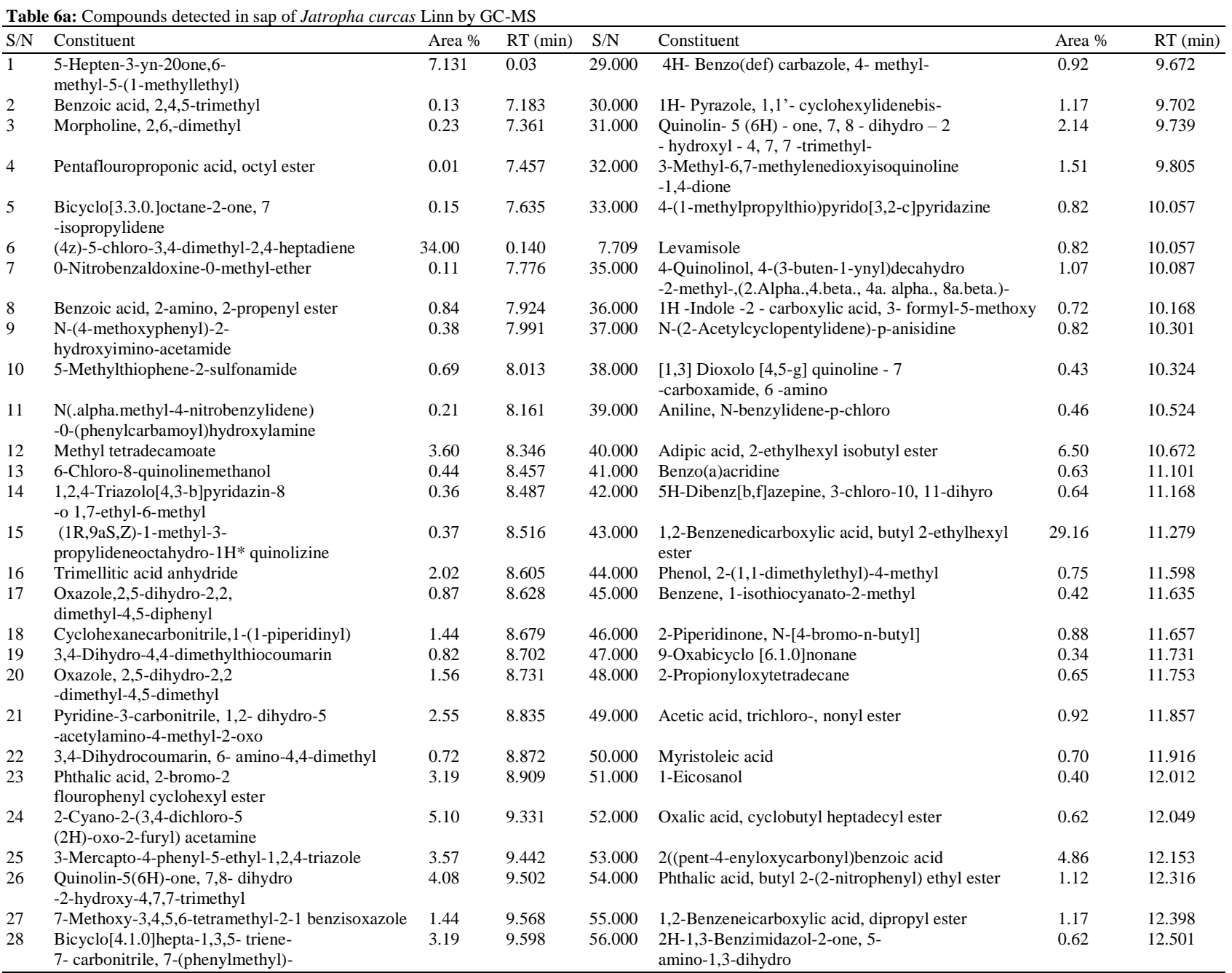

Table 6b: Compounds detected in methanolic extract of stem bark of Jatropha curcas Linn by GC-MS

\begin{tabular}{|c|c|c|c|c|c|c|c|}
\hline $\mathrm{S} / \mathrm{N}$ & Constituent & Area \% & $\mathrm{RT}(\min )$ & $\mathrm{S} / \mathrm{N}$ & Constituent & Area $\%$ & $\mathrm{RT}(\min )$ \\
\hline 1 & 2H-pyran, 2-(3-butylnyloxy)tetrahydro & 0.02 & 7.354 & 24 & 2-Chloroethyl vinyl sulfide & 0.23 & 9.176 \\
\hline 2 & 3,4 -Furandiol, tetrahydro, cis & 0.05 & 7.435 & 25 & Desulphosinigrin & 0.25 & 9.213 \\
\hline 3 & 11-(2-cyclopenten-1-yl)undecanoic acid, (+) & 0.03 & 7.480 & 26 & Acetamide, 2-amino-N-phenyl-2-thioxo & 0.28 & 9.265 \\
\hline 4 & Cyclobut-1-enylmethanol & 0.03 & 7.517 & 27 & 7,Oabicyclo[4.1.0]heptanes, 1,5-dimethyl & 7.70 & 9.524 \\
\hline 5 & Cyclobutanone, 2-methyl-2-oxiranyl & 0.03 & 7.546 & 28 & 8-Hexadecenal, 14-methyl-, (z) & 3.80 & 9.865 \\
\hline 6 & 3,3'-Iminobispropylamine & 0.03 & 7.621 & 29 & Dichloroacetic acid, 2-pentadecyl ester & 11.68 & 10.302 \\
\hline 7 & 2H-Pyran, tetrahydro-2-(2,2,2-triflouroethoxy) & 0.03 & 7.665 & 30 & Aspidospermidin-17-ol, 1-acetyl-19, 21-epoxy-15,16- & 1.69 & 10.354 \\
\hline 8 & 2ᄀ-Hexene, 1-chloro & 0.04 & 7.695 & 31 & Hexadecenoic acid, z-11 & 3.40 & 10.428 \\
\hline 9 & Pent-3-enylamine & 0.06 & 7.902 & 32 & Pentadecanoic acid & 1.57 & 10.783 \\
\hline 10 & 2(3H)Furanone & 0.02 & 7.976 & 33 & Cis-9-Hexadecenoic acid & 1.67 & 10.828 \\
\hline 11 & 4-Chloro-3-n-butyltetrahydropyran & 0.21 & 8.087 & 34 & 9-Oxabicyclo[6.1.0.]nonane & 2.45 & 10.902 \\
\hline 12 & Heptamethylene diacetate & 0.12 & 8.169 & 35 & Oxacyclotetradecan-2-one & 3.29 & 10.976 \\
\hline 13 & $(s)(+)$-z-13-methyl-11-pentadecen-1-ol acetate & 0.07 & 8.220 & 36 & 5-Octadecenal & 1.26 & 11.005 \\
\hline 14 & 2-Allyl-2-methyl-1,3cyclopentanedione & 0.54 & 8.398 & 37 & E-11-Tetradecenoic acid & 1.76 & 11.050 \\
\hline 15 & Acetamide, $\mathrm{N}$-isoxazolo[5,4-b] pyridine-3-yl & 0.68 & 8.487 & 38 & 9-Hexadecenoic acid & 1.19 & 11.079 \\
\hline 16 & $\begin{array}{l}\text { Spiro \{6,6-dimethyl-2,3-diazobicyclo [3.1.0] } \\
\text { hex-2-ene-4,1'-cyclopropane }\}\end{array}$ & 3.23 & 8.509 & 39 & Methyl 12-oxo-9-dodecenoate & 0.96 & 11.102 \\
\hline 17 & $\begin{array}{l}\text { 5. alpha.-Androstan-16-one, } \\
\text { cyclicethylene mercaptole }\end{array}$ & 2.62 & 8.591 & 40 & Myristoleic acid & 3.72 & 11.161 \\
\hline 19 & $\begin{array}{l}\text { (3-Chlorophenyl) carbamic acid, 5,6 } \\
\text {,7,8-tetrahydronaphthalen-2-yl ester }\end{array}$ & 9.78 & 8.865 & 42 & Acetic acid, trichloro-, nonyl ester & 0.07 & 11.916 \\
\hline 20 & Benzene, 1-isocyanato-3-methoxy & 0.39 & 8.87 & 43 & 1-Decanol, 2-octyl & 1.44 & 12.035 \\
\hline 21 & Benzene, 2[(2-methyl-2-propennyl) oxy] & 0.56 & 8.909 & 44 & 2-Propenoic acid, tridecyl ester & 2.47 & 12.190 \\
\hline 22 & Propane, 1,3-bis(propylthio) & 0.80 & 8.939 & 45 & Oxalic acid, cyclobutyl hexadecyl ester & 0.47 & 12.250 \\
\hline 23 & $\begin{array}{l}\text { Spiro[azetidin-2-one-4,2'-tricyclo } \\
(3,3,1,1(3,7) \text { decane] }\end{array}$ & 1.91 & 9.043 & 46 & $\begin{array}{l}\text { 1,2-Benzenedicarboxylic acid, bis } \\
\text { (2-ethylbutyl) ester dimethoxy- }\end{array}$ & 2.88 & 12.316 \\
\hline
\end{tabular}




\begin{tabular}{|c|c|c|c|c|c|c|c|}
\hline $\mathrm{S} / \mathrm{N}$ & Constituent & Area $(\%)$ & $\mathrm{RT}(\min )$ & $\mathrm{S} / \mathrm{N}$ & Constituent & Area $(\%)$ & $\mathrm{RT}(\mathrm{min})$ \\
\hline$\overline{1}$ & 2H-pyran, 2-(3-butylnyloxy)tetrahydro & 0.23 & 8.220 & 27 & Cyclohexanone, 4- hydroxy- & 0.62 & 10.791 \\
\hline 2 & Cyclopentanone & 0.27 & 8.332 & 28 & 9- Octadecenal, (z)- & 0.69 & 10.835 \\
\hline 3 & 6, 7- Dimethyl- triazolo $(4,3-b)(1,2,4)$-triazine & 1.41 & 8.591 & 29 & Dodecyl isobutyl carbonate & 1.37 & 10.998 \\
\hline 4 & $\begin{array}{l}\text { 5. Alpha. -Androstan- } 16 \text {-one, cyclc } \\
\text { ethylene marcaptole }\end{array}$ & 0.34 & 8.620 & 30 & 8- Hexacenal, 14-methyl-, (z)- & 1.80 & 11.072 \\
\hline 5 & 10- Azido - 1 -decanethiol & 0.28 & 8.650 & 31 & Z- 7- Tetradecenoic acid & 1.20 & 11.124 \\
\hline 6 & Paromomycin & 0.71 & 8.731 & 32 & E- 11- Tetradecenoic acid & 0.59 & 11.161 \\
\hline 8 & Hydroquinone, acetate & 1.96 & 8.80 & 34 & Decanoic acid, 2,3- dihydroxypropyl ester & 1.77 & 11.390 \\
\hline 9 & s- Triazolo [4,3-a] pyrazine, 5,8- dimethyl- & 1.05 & 8.931 & 35 & cis- 9- Hexadecenoic acid & 1.65 & 11.450 \\
\hline 10 & 9- Oxabicyclo[6.1.0]none- 4 -one & 0.68 & 9.465 & 36 & 10- Octadecenal & 1.23 & 11.479 \\
\hline 11 & Allyl methallyl ether & 0.45 & 9.502 & 37 & Ricinoleic acid & 8.36 & 11.679 \\
\hline 12 & E- 1, 6- Undecadiene & 1.00 & 9.546 & 38 & 2- Piperidinone, $\mathrm{N}$ - [4- bromo- $\mathrm{n}$ - butyl]- & 2.37 & 11.731 \\
\hline 13 & 1- Nitro -.beta. - d- arabinofuranose, tetraacetate & 0.26 & 9.887 & 39 & 4- Octadecenal & 2.44 & 11.827 \\
\hline 14 & Acetic acid, 10- chlorodecyl ester & 0.33 & 9.983 & 40 & 7- Hexadecenal, (Z)- & 3.03 & 11.879 \\
\hline 16 & Hexadecane, 1,1- bis(dodecyloxy)- & 0.24 & 10.117 & 42 & Oxirane, tetradecyl- & 2.81 & 11.953 \\
\hline 17 & Vinyl lauryl ether & 0.27 & 10.161 & 43 & L- Homoserine lactone, $\mathrm{N}, \mathrm{N}$ - dimethyl & 7.44 & 12.057 \\
\hline 18 & Oxacyclotetradecan- 2-one, 13- methyl- & 0.58 & 10.250 & 44 & 17- Pentatriacontene & 3.49 & 12.161 \\
\hline 19 & Myristoleic acid & 1.36 & 10.383 & 45 & Oxalic acid, allyl hexadecyl ester & 6.45 & 12.250 \\
\hline 20 & Dodenoic acid, 1- methylethyl ester & 0.35 & 10.413 & 46 & 7- methylthieno[3,2-b] pyridine & 5.94 & 12.324 \\
\hline 21 & 2- Tridecenal, (E)- & 0.30 & 10.442 & 47 & Phthalic acid, ethyl 4- methylpent- 2- yl ester & 7.59 & 12.361 \\
\hline 22 & cis- Hexadecenoic acid & 0.67 & 10.487 & 48 & 6- Bromohexanoic acid, octyl ester & 0.44 & 13.390 \\
\hline 23 & E-9- Tetradecenoic acid & 0.39 & 10.524 & 49 & d- Glucitol, 1, 5- hexyl-1- thio & 0.23 & 13.420 \\
\hline 24 & 5- Octadecenal & 0.32 & 10.554 & 50 & 7- Hydroxy-3- (1, 1-dmethylprop-2- enyl)coumarin & 0.44 & 13. 464 \\
\hline 25 & 7- Hexadecenal, (z)- & 0.81 & 10.679 & 51 & d- Mannitol, 1- thiooctyl- 1- deoxy- & 1.04 & 13.827 \\
\hline 26 & 1- Hentetracontanol & 0.68 & 10.753 & 52 & $\begin{array}{l}\text { Pyrrolidine, 1- methyl- 3,2'-spiro } \\
\text { - benzo-1, 3-dioxolane }\end{array}$ & 7.05 & 14.005 \\
\hline
\end{tabular}

This compounds were reported to have antihistaminica, antiacne, antiandrogenic, antiarthritic and anticoronary activities. In addition, the compound is of 5-Alpha reductase inhibitor Insectifuge. (3-Chlorophenyl) carbamic acid, 5,6,7,8-tetrahydronaphthalen, dichloroacetic acid and 2pentadecyl ester is also known to have anti-inflammatory, diuretic and antimicrobial activity (Lingen et al., 1959; Yayli et al., 2006; Muthulakshmi and Mohan, 2012).

\section{Discussion}

The intractable problems of antimicrobial resistance and poverty has led to the resurgence of interest in herbal products as sources of novel compounds, to suppress or possibly eradicate the ever increasing problems of emergence of newer diseases (Wurochekke et al., 2008; Ekundayo et al., 2011). Traditionally, different parts of Jatropha curcas Linn have been used in treatment of different forms of infection (Namuli et al., 2011). Like findings of this study, Candida species have earlier been reported as the most frequently isolated invasive fungal pathogen in humans, with the majority of infections being localized to the urogenital or oropharyngeal tracts of the patient (Fidel and Sobel, 1996).

Phytochemicals such as alkaloids, terpenoids, saponins and phenolics are considered as strong antimicrobial agents that can aid in solving the problem of antibiotic resistance (Gupta et al., 2011). Tannins and alkaloids showed high amount next to phenol in this study Tannins have been found to form irreversible complexes with prolinerich protein (Shimada, 2006). Alkaloids which are one of the largest groups of phytochemicals in plants having amazing effects on humans and this has led to the development of powerful pain killer medications as reported by (Kam and Liew, 2002; Doughari, 2012). The absence of alkaloids in Jatropha curcas Linn leaf extracts had also been reported by (Kubmarawa et al., 2007; Akinpelu et al., 2009). In this study however alkaloids were present in Jatropha curcas Linn stem bark, sap and leaves extracts respectively. These compounds have been associated with medicinal uses for centuries and were reported as the most efficient and therapeutically significant plant substance (Njoku and Akumefula, 2007).

The methanol extracts of stem bark and leaves (crude and methanol fraction), showed low antimicrobial activity at $200 \mu \mathrm{g} / \mathrm{mL}$ (Table 4a). But with increase in concentration to $1000 \mu \mathrm{g} / \mathrm{mL}$, highest antimicrobial activity of $(13.00 \mathrm{~mm}$ diameter of zone of inhibition) was observed (Table 4b). Different parts of methanol extract of Jatropha curcas Linn had the highest activity against both bacterial and fungal isolates and the least was observed in the water extract. Methanol is believed to be suitable solvent for extraction, because of high polarity to extract relatively high percentage phytochemical, such as phenols and terpenoids than the aqueous solvent, (Srinivasan et al., 2001; Caunii et al., 2012). The ability of the methanol extracts of the leaf and stem bark of Jatropha curcas Linn to inhibit growth of the test organism more than the aqueous extracts are an indication of their antimicrobial potency which may be employed in treatment of microbial infections (Ekundayo et al., 2011). 
In their separate studies, (Aransiola et al., 2014; Abubakar et al., 2016) had earlier reported that Jatropha curcas Linn sap have varied antibacterial and antifungal activities against bacteria and Candida species which suggests that, the sap of this plant has broad spectrum of activities. Also (Srinivasan et al., 2001) reported that different solvents have different extraction capacities and different spectrum of solubility for the phyto-constituents. The inhibitory activity of plant extracts is also largely dependent on the concentration, parts of the plant used and the microbe tested (Kalimuthu et al., 2010). Results also showed that the aqueous extracts of Jatropha curcas Linn leaf and stem bark had lower inhibitory activity compared to its organic extracts. This study however is in disagreement with the findings of (Dada et al., 2014) that aqueous extract of Jatropha curcas Linn leaves showed potent antibacterial activities on coliforms than methanol and acetone extracts. The organic extracts provided denaturation and increase the permeability of cell membranes in microorganism (Farag et al., 1989).

MIC and MFC values are measures of efficacy of an antimicrobial agent (Doughari, 2012). It can therefore be seen that the various extracts of Jatropha curcas Linn have potential efficacy against Candida albicans. The different compounds isolated from various parts of Jatropha curcas in this study have earlier been reported to be effective antimicrobial agents. Hence, the potential antibacterial activity and antifungal activity of Jatropha curcas Linn against microorganisms may be explained on the basis of the presence of these bioactive phytoconstituents (Kim et al., 2009; Volpicella et al., 2011).

The GC-MS result from the sap extracts is in agreement with the study by (Akinpelu et al., 2009; Igbinosa et al., 2009) who also reported the presence of flavonoids, phenols and alkaloids in the sap extracts. Flavonoids, phenols and alkaloids have antibacterial, antifungal, antimalarial, analgesic anti-inflammatory and antiviral effects (Oksana et al., 2007). The compounds are reported to have very promising biological activities as anticancer, anticonvlsant, antituberculosis, antialzheimer's, pain relief, antidermatitis and antimicrobial agents (Youssef and Amin, 2010). Recently spiro compounds have been also used as antioxidants (Sarma et al., 2010). Tetradecanoic acid and squalene have the property of antioxidant activity (Kala et al., 2011). Deconoate salt and esters of various drugs are available. Since decanoic acid is a fatty acid, forming a salt or ester with a drug will increase its lipophilicity and its affinity for fatty tissue compounds found in the methanol leaves extract of Jatropha curcas Linn are being used for the pharmacological work (Kala et al., 2011). The antimicrobial activity of Jatropha curcas may be related to the inhibition of the enzymes catalytic action via formation of stoichiometric complex with the target enzymes resulting in the blocking or alteration of their active sites (Lingen et al., 1959; Yayli et al., 2006; Muthulakshmi and Mohan, 2012). These therefore, account for the antimicrobial activity of Jatropha curcas Linn and its local application to treat different ailments.

\section{Conclusion}

From this present study, it can be concluded that Jatropha curcas Linn has demonstrated antifungal activity against Candida albicans and Candida tropicalis associated with neonatal and infantile infections, justifying its traditional use by herbalists as health remedy in infants. Jatropha curcas Linn., therefore possesses the potential of being processed in to drugs for human consumption against neonatal and infantile infections as well. However, further research needs be conducted to determine the chemical structure and respective roles of various phytoconstituents identified in the plant parts in respect of antimicrobial activity with the view to purifying them for drug development. Toxicological studies to determine their safety to humans and effect of the plant against a wider range of fungi and bacteria should also be explored.

\section{Declarations:}

- No funding was received for conducting this study

- The authors have no conflicts of interest to declare that are relevant to the content of this article

- Ethics Approval and Consent to Participate

Manuscripts reporting studies involving human participants, human data or human tissue must:

- Ethics approval and consent to participate no. ADHM/EC/2019/R00271 was obtained from the Ethics Committee, Adamawa State Ministry of Health, Yola, Nigeria

- Include a statement on ethics approval and consent (even where the need for approval was waived)

\section{Consent for Publication}

Manuscript does not contain any individual person's data in any form (including individual details, images or videos), that requires consent to publish.

\section{Availability of Data and Material}

"Data sharing not applicable to this article as no datasets were generated or analyzed during the current study." 


\section{Acknowledgement}

The authors appreciate the Department of Microbiology, MAUTECH, Yola for making the laboratory available for this research.

\section{Authors' Contributions}

James Hamuel Doughari: Designed the research plan, organized the study, edited, proof read and approved the manuscript.

Martha Abraham: Participated in all experiments, coordinated the dataanalysis and contributed to the writing of the manuscript.

\section{Conflict of Interest}

"James Hamuel Doughari and Martha Abraham declare that they have no conflict of interest."

\section{References}

Abubakar, S., Akanbi, B. O., Osuji, C., Olagide, O. O., \& Philip, C. A. (2016). Evaluation of pharmacological potentials of Jatropha curcas Linn sap Euphobiaceae family. Pharmaceutical and Biological Evaluation, [S. I.] (3).3: 334-342.

Akinpelu, D. A., Aiyegoro, O. A., \& Okoh, A. I. (2009). The bioactive potentials of two medicinal plants commonly used as folklore remedies among some tribes in West Africa. African Journal of Biotechnology, 8(8). https://www.ajol.info/index.php/ajb/article/view/6 0361

Anwer, N., Waqar, M. A., Iqbal, M., Mushtaq, M., \& Sobia, A. (2013). Phytochemical analysis, free radical scavenging capacity and antimicrobial properties of Impatiens bicolor plant. International Food Research Journal, 20(1).

Aransiola, M. N., Ehikhase, C., Mmegwa, J. C., \& Wahab, I. O. (2014). Antibacterial and antifungal activities of Jatropha multifida (Ogege) sap against some pathogens. IOSR Journal of Pharmacy and Biological Sciences, 9(4), 53-7. https://doi.org/10.9790/3008-09415357

Arekemase, M. O., Kayode, R. M. O., \& Ajiboye, A. E. (2011). Antimicrobial activity and phytochemical analysis of Jatropha curcas plant against some selected microorganisms. International Journal of Biology, 3(3), 52. https://doi.org/10.5539/ijb.v3n3p52

Bhavan, P. S., Rajkumar, R., Radhakrishnan, S., Seenivasan, C., \& Kannan, S. (2010). Culture and Identification of Candida albicans from Vaginal Ulcer and Separation of Enolase on SDS-PAGE. International Journal of Biology, 2(1), 84. https://doi.org/10.5539/ijb.v2n1p84
Borman, A. M., Fraser, M., Palmer, M. D., Szekely, A., Houldsworth, M., Patterson, Z., \& Johnson, E. M. (2017). MIC distributions and evaluation of fungicidal activity for amphotericin B, itraconazole, voriconazole, posaconazole and caspofungin and 20 species of pathogenic filamentous fungi determined using the CLSI broth microdilution method. Journal of Fungi, 3(2), 27. https://doi.org/10.3390/jof3020027

Caunii, A., Pribac, G., Grozea, I., Gaitin, D., \& Samfira, I. (2012). Design of optimal solvent for extraction of bioactive ingredients from six varieties of Medicago sativa. Chemistry Central Journal, 6(1), 1-8. https://doi.org/10.1186/1752-153X-6-123

Cheesbrough, M. (2005). District laboratory practice in tropical countries, part 2. Cambridge university press. ISBN-10: 0521676312.

Chen, Y., Xie, M. Y., \& Gong, X. F. (2007). Microwaveassisted extraction used for the isolation of total triterpenoid saponins from Ganoderma atrum. Journal of Food Engineering, 81(1), 162-170. https://doi.org/10.1016/j.jfoodeng.2006.10.018

Dada, E. O., Ekundayo, F. O., \& Makanjuola, O. O. (2014). Antibacterial activities of Jatropha curcas (LINN) on coliforms isolated from surface waters in Akure, Nigeria. International Journal of Biomedical Science: $\quad$ IJBS, $10(1), \quad 25$. https://www.ncbi.nlm.nih.gov/pmc/articles/pmc3976 444/

Das, K., Tiwari, R. K. S., \& Shrivastava, D. K. (2010). Techniques for evaluation of medicinal plant products as antimicrobial agent: Current methods and future trends. Journal of Medicinal Plants Research, 4(2), 104-111.

Doughari, J. H. (2012). Phytochemicals: extraction methods, basic structures and mode of action as potential chemotherapeutic agents. PhytochemicalsA Global Perspective of their Role in Nutrition and health, 3, 1-27.

Ekundayo, F. O., Adeboye, C. A., \& Ekundayo, E. A. (2011). Antimicrobial activities and phytochemical screening of pignut (Jatrophas curcas Linn.) on some pathogenic bacteria. Journal of Medicinal Plants Research, 5(7), 1261-1264. http://citeseerx.ist.psu.edu/viewdoc/download?doi=1 $0.1 .1 .1006 .5450 \&$ rep $=$ rep $1 \&$ type $=$ pdf

El-Baz, F. K., Bagato, O., Aly, H. F., Saad, S. A., Ali, M. A., \& Mohamed, A. A. (2015). Comparative evaluation of Jatropha curcas leaves extract for antibacterial, antiavian influenza a virus (H5NI) properties and GC-MS profile. International Journal of Pharma and Bio Sciences, 6(2), 108-120.

Esimone, C. O., Adikwu, M. U., \& Okonta, J. M. (1998). Preliminary antimicrobial screening of the ethanolic extract from the lichen Usnea subfloridans (L). American Journal of Microbiological Research, 3(2), 99-101. http://www.sciepub.com/reference/141636 
Farag, R. S., Dawz, Y., Hawedi, A., \& El- Boruly, G. S. A. (1989). Antimicrobial Activity of Some Egypian Species Essential Oils. Journal of Food Protection, 52: 665-667. https://doi.org/10.4315/0362-028X-52.9.665

Fidel, P. L., \& Sobel, J. D. (1996). Immunopathogenesis of recurrent vulvovaginal candidiasis. Clinical Microbiology Reviews, 9(3), 335-348. https://doi.org/10.1128/CMR.9.3.335

Gupta, D. D., Haque, M. E., Islam, M. N., Rahman, S., Hasan, A. M., \& Shibib, B. A. (2011). Alkaloid and steroid from the stem bark of Jatropha curcas (Euphorbiaceae). Dhaka University Journal of Pharmaceutical Sciences, 10(1), 9-11. https://doi.org/10.3329/dujps.v10i1.10009

Igbinosa, O. O., Igbinosa, E. O., \& Aiyegoro, O. A. (2009). Antimicrobial activity and phytochemical screening of stem bark extracts from Jatropha curcas (Linn). African Journal of Pharmacy and Pharmacology, 3(2), 058-062. https://citeseerx.ist.psu.edu/viewdoc/download?doi= 10.1.1.561.1288\&rep=rep1\&type $=$ pdf

Ishak, N. D., Ismail, J., \& Assim, Z. (2011). Antifungal activity of Jatropha curcas pericarps and leaves extracts. Universiti Malaysia Sarawak.

Jha, N. K., Pande, K. L., \& Jha, A. K. (2006). Jatropha Carcus Linn: Jangali Erand. Phytopharmacy, 7: 3-8.

Kala, S. M. J., Balasubramanian, T., Soris, P. T., \& Mohan, V. R. (2011). GC-MS determination of bioactive components of Eugenia singampattiana Bedd. International Journal of ChemTech Research, 3(3),

1534-1537. https://www.academia.edu/download/33398807/Pha rmtech-_singampattiana.pdf

Kalimuthu, K., Vijayakumar, S., \& Senthilkumar, R. (2010). Antimicrobial activity of the biodiesel plant, Jatropha curcas L. International Journal of Pharma and Bio Sciences, 1(3), 1-5. http://citeseerx.ist.psu.edu/viewdoc/download?doi=1 0.1.1.178.2753\&rep=rep1\&type $=$ pdf

Kam, P. C. A., \& Liew, S. (2002). Traditional Chinese herbal medicine and anaesthesia. Anaesthesia, 57(11), 1083-1089. https://doi.org/10.1046/j.13652044.2002.02823.X

Kim, J. Y., Park, S. C., Hwang, I., Cheong, H., Nah, J. W., Hahm, K. S., \& Park, Y. (2009). Protease inhibitors from plants with antimicrobial activity. International Journal of Molecular Sciences, 10(6), 2860-2872. https://doi.org/10.3390/ijms10062860

Kubmarawa, D., Ajoku, G. A., Enwerem, N. M., \& Okorie, D. A. (2007). Preliminary phytochemical and antimicrobial screening of 50 medicinal plants from Nigeria. African Journal of Biotechnology, 6(14). https://www.ajol.info/index.php/ajb/article/view/57755
Lingen, C., Ernster, L., \& Lindberg, O. (1959). The promoting effect of lycopene on the non-specific resistance of animals. Experimental Cell Research, 16(2), 384-393. https://doi.org/10.1016/00144827(59)90267-8

Matare, T., Nziramasanga, P., Gwanzura, L., \& Robertson, V. (2017). Experimental germ tube induction in Candida albicans: An evaluation of the effect of sodium bicarbonate on morphogenesis and comparison with pooled human serum. Biological Medicine Research International, 2017. https://doi.org/10.1155/2017/1976273

Mpofu, A., Kock, J. L. F., Pretorious, E. E., Pohl, C. H., \& Zvauya, R. (2008). Identification of yeasts isolated from mukumbi, a Zimbabwean traditional wine. Journal Sustain Develop. Afr, 10, 88-102. http://citeseerx.ist.psu.edu/viewdoc/download?doi=1 0.1.1.578.480\&rep=rep1\&type $=$ pdf

Muthulakshmi, A. R. J. M., \& Mohan, V. R. (2012). GCMS analysis of bioactive components of Feronia elephantum Correa (Rutaceae). Journal of Applied $\begin{array}{lll}\text { Pharmaceutical } & \text { Science, } & \text { 2(2), }\end{array}$ https://www.japsonline.com/admin/php/uploads/382 _pdf.pdf

Namuli, A., Abdullah, N., Sieo, C. C., Zuhainis, S. W., \& Oskoueian, E. (2011). Phytochemical compounds and antibacterial activity of Jatropha curcas Linn. extracts. Journal of Medicinal Plants Research, 5(16), 3982-3990.

Njoku, P. C., \& Akumefula, M. I. (2007). Phytochemical and nutrient evaluation of Spondias mombin leaves. Pakistan Journal Nutr, 6(6), 613-615. https://doi.org/10.3923/pjn.2007.613.615

Nwala, O. C., Akaninwor, J. O., \& Monanu, M. O. (2013). Use of extracts of Jatropha Curcas leaf formulated in a simple ointment base in wound healing activities: how safe is it. International Journal of Engineering Science Invention, 2(6), 53-57.

Obidi, O. F., Adelowotan, A. O., Ayoola, G. A., Johnson, O. O., Hassan, M. O., \& Nwachukwu, S. C. U. (2013). Antimicrobial Activity Of Orange Oil On Selected Pathogens. http://www.aessweb.com/pdffiles/ijb\%202(6),\%20113-122.pdf

Oksana, J., Sabin, O., Adriana, M., Virginia, Z., Susana, F., \& Graciela, H. (2007) Phytochemical Analysis and Antifungal Evaluation of Sebastiania commersoniana Extracts. Pharmaceutical Biology, 45 (3): 404-406. https://doi.org/10.1080/13880200701215216

Pappas, P. G. (2006). Invasive candidiasis. Infectious Disease Clinics, 20(3), 485-506. https://doi.org/10.1016/j.idc.2006.07.004

Rahmoun, N. M., Boucherit-Atmani, Z., Benabdallah, M., Boucherit, K., Villemin, D., \& Choukchou-Braham, N. (2013). Antimicrobial activities of the henna extract and some synthetic naphthoquinones derivatives. American Journal Medicine Biological Research, 1(1), 16-22. https://doi.org/10.12691/ajmbr-1-1-3 
Romani, L. (2008). Cell mediated immunity to fungi: a reassessment. Sabouraudia, 46(6), 515-529. https://doi.org/10.1080/13693780801971450

Sarma, B. K., Manna, D., Minoura, M., \& Mugesh, G. (2010). Synthesis, structure, spirocyclization mechanism and glutathione peroxidase-like antioxidant activity of stable spirodiazaselenurane and spirodiazatellurane. Journal of the American Chemical Society, 132(15), 5364-5374. https://doi.org/10.1021/ja908080u

Shimada, T. (2006). Salivary proteins as a defense against dietary tannins. Journal of chemical ecology, 32(6), 1149-1163. https://doi.org/10.1007/s10886-006-9077-0

Sofowora, A. (1996). Medicinal plants and traditional medicine in Africa. Karthala. https://www.cabdirect.org/cabdirect/abstract/1998 6772939

Srinivasan, D., Nathan, S., Suresh, T., \& Perumalsamy, P. L. (2001). Antimicrobial activity of certain Indian medicinal plants used in folkloric medicine. Journal of Ethnopharmacology, 74(3), 217-220. https://doi.org/10.1016/S0378-8741(00)00345-7

Sundari. J., \& Selvaraj, R. (2011). Antibacterial and Antifungal Activity of Seed Extract from Jatropha carcus Linn. International Journal of Current Research. 3.3.6. pp. 084-087. Peptide Science, 12, 386-398. http://journalcra.com/sites/default/files/issuepdf/731.pdf

Tiwari, K. B., Shrestha, M. L., \& Agrawal, V. P. (2007). Abundance of lactose assimilating yeasts from Nepalese Murcha (Yeast cake). International Journal of Life Sciences, 1, 1-5. https://doi.org/10.3126/ijls.v1i0.2299
Ujjwal, N., Ruchi, S., Rashmi, K. M., \& Raju, K. C. (2008)'"Lipid Content and Nitro Antimicrobial Activity of Oil Seeds of Some Indian Medical Plants". Current Research in Bacteriology, 1. 1-6. https://doi.org/10.3923/crb.2008.1.6

Volpicella, M., Leoni, C., Costanza, A., De Leo, F., Gallerani, R., \& R Ceci, L. (2011). Cystatins, serpins and other families of protease inhibitors in plants. Current Protein and Peptide Science, 12(5), 386-398. https://doi.org/10.2174/138920311796391098

Joanne, M. W., Linda, M. S., \& Christopher, J. W. (2008). Prescott, Harley and Klein's microbiology. McGraw-Hill. Higher Education.

Wurochekke, A. U., Anthony, A. E., \& Obidah, W. (2008). Biochemical effects on the liver and kidney of rats administered aqueous stem bark extract of Xemenia Americana. African Journal of Biotechnology, 7(16).

Yayli, N., Gülec, C., Üçüncü, O., Yaşar, A., Ülker, S., Coşkunçelbi, K., \& Terzioğlu, S. (2006). Composition and antimicrobial activities of volatile components of Minuartia meyeri. Turkish Journal of Chemistry, 30(1), 71-76. https://journals.tubitak.gov.tr/chem/abstract.htm?id= 8093

Youssef, M. M., \& Amin, M. A. (2010). Microwave assisted synthesis of some new heterocyclic spiroderivatives with potential antimicrobial and antioxidant activity. Molecules, 15(12), 8827-8840. https://doi.org/10.3390/molecules 15128827 